\title{
Latitudinal patterns in intertidal ecosystem structure in West Greenland suggest resilience to climate change
}

\author{
Jakob Thyrring, Susse Wegeberg, Martin E. Blicher, Dorte Krause-Jensen, Signe Høgslund, Birgit Olesen, \\ Jozef Wiktor Jr., Kim N. Mouritsen, Lloyd S. Peck and Mikael K. Sejr
}

\begin{abstract}
J. Thyrring (https://orcid.org/0000-0002-1029-3105) ■ (jakyrr57@bas.ac.uk) and L. S. Peck (https://orcid.org/0000-0003-3479-6791), British Antarctic Survey, Cambridge, UK. JT also at: Dept of Zoology, Univ. of British Columbia, Vancouver, British Columbia, Canada. - S. Wegeberg, D. Krause-Jensen (https://orcid.org/0000-0001-9792-256X), K. N. Mouritsen (https://orcid.org/0000-0003-3564-8328) and M. K. Sejr (https://orcid.org/0000-00018370-5791), Arctic Research Centre, Aarhus Univ., Denmark. SW also at: Arctic Environment, Dept of Bioscience, Aarhus Univ., Roskilde, Denmark. M. E. Blicher, Greenland Climate Research Centre, Greenland Inst. of Natural Resources, Nuuk, Greenland. - S. Høgslund, DK-J, (https://orcid. org/0000-0001-5926-8464) and MKS, Marine Ecology, Dept of Bioscience, Aarhus Univ., Silkeborg, Denmark. - B. Olesen (https://orcid.org/0000-00028864-6716) and KNM, Aquatic Biology, Dept of Biology, Aarhus Univ., Aarhus C, Denmark. - J. Wiktor Jr., Inst. of Oceanology, Polish Academy of Sciences, Sopot, Poland.
\end{abstract}

\section{Ecography}

44: $1-13,2021$

doi: $10.1111 /$ ecog. 05381

Subject Editor: Eric Post Editor-in-Chief: Miguel Araújo Accepted 30 March 2021
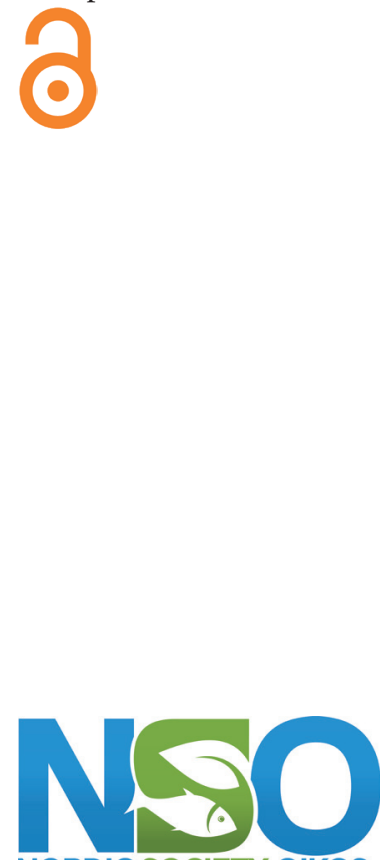

NORDIC SOCIETY OIKOS

www.ecography.org
Climate change has ecosystem-wide cascading effects. Little is known, however, about the resilience of Arctic marine ecosystems to environmental change. Here we quantify and compare large-scale patterns in rocky intertidal biomass, coverage and zonation in six regions along a north-south gradient of temperature and ice conditions in West Greenland $\left(60-72^{\circ} \mathrm{N}\right)$. We related the level and variation in assemblage composition, biomass and coverage to latitudinal-scale environmental drivers. Across all latitudes, the intertidal assemblage was dominated by a core of stress-tolerant foundation species that constituted $>95 \%$ of the biomass. Hence, canopy-forming macroalgae, represented by Fucus distichus subsp. evanescens and F. vesiculosus and, up to $69^{\circ} \mathrm{N}$, also Ascophyllum nodosum, together with Semibalanus balanoides, occupied $>70 \%$ of the vertical tidal range in all regions. Thus, a similar functional assemblage composition occurred across regions, and no latitudinal depression was observed. The most conspicuous difference in species composition from south to north was that three common species (the macroalgae Ascophyllum nodosum, the amphipod Gammarus setosus and the gastropod Littorina obtusata) disappeared from the mid-intertidal, although at different latitudes. There were no significant relationships between assemblage metrics and air temperature or sea ice coverage as obtained from weather stations and satellites, respectively. Although the mean biomass decreased $>50 \%$ from south to north, local biomass in excess of $10000 \mathrm{~g} \mathrm{ww} \mathrm{m}^{-2}$ was found even at the northernmost site, demonstrating the patchiness of this habitat and the effect of small-scale variation in environmental characteristics. Hence, using the latitudinal gradient in a space-for-time substitution, our results suggest that while climate modification may lead to an overall increase in the intertidal biomass in north Greenland, it is unlikely to drive dramatic functional changes in ecosystem structure in the near future. Our dataset provides an important baseline for future studies to verify these predictions for Greenland's intertidal zone.

Keywords: Arctic, benthos, biogeography, climate change, range shifts, space-for-time

(C) 2021 The Authors. Ecography published by John Wiley \& Sons Ltd on behalf of Nordic Society Oikos This is an open access article under the terms of the Creative Commons Attribution License, which permits use, distribution and reproduction in any medium, provided the original work is properly cited. 


\section{Introduction}

The rocky intertidal zone is one of the most studied marine habitats, and has provided a wealth of information about the ecological processes that shape assemblage structure and dynamics. The Arctic accounts for more than $30 \%$ of the world's coastline (Lantuit et al. 2012), but Arctic intertidal habitats have received little attention, and rocky Arctic shores were until recently thought to be sparsely colonized (Ellis 1955, Węsławski et al. 1993). Scattered studies from different sub-Arctic and Arctic rocky shores on Svalbard (Kuklinski and Barnes 2008, Węsławski et al. 2010, 2018), Iceland (Ingolfsson 1992, Ingólfsson 1996) and southern Greenland (Blicher et al. 2013, Høgslund et al. 2014, Sejr et al. 2021) have documented species diversity, and revealed high biomasses locally, but most of the Arctic intertidal zone remains unexplored. For instance, the physical parameters driving regional differences, and the rates of change in key ecosystem metrics, such as biomass and coverage, remain poorly understood, hindering assessments of climate change effects on the ecosystem. At lower latitudes, several studies have highlighted the intertidal zone as a harbinger of climate change impacts (Barry et al. 1995, Helmuth et al. 2002), showing that increasing temperatures force boreal intertidal species poleward (Pitt et al. 2010, Sanford et al. 2019), potentially causing ecosystem-wide effects as non-native foundation species establish, or natives disappear (Sorte et al. 2017). Although, the Arctic is warming at rates 2- to 3-fold greater than the global average (AMAP 2017), the scarcity of Arctic baseline and time-series data prevent quantifications of how this rapid warming affects intertidal organisms and ecosystem functioning.

Located in the middle of the North Atlantic, Greenland spans more than 20 degrees of latitude covering both subArctic and Arctic ecosystems. In addition to the latitudinal gradient, the surrounding ocean currents create biogeographic differences between Greenland's east and west coast. West Greenland is influenced by north-flowing warm water of Atlantic origin, while the East Greenland coast is dominated by cold south-flowing polar water from the central Arctic ocean via the East Greenland current. As a consequence, ocean temperatures, sea ice coverage and connectivity to source populations vary greatly around Greenland. Along the west coast, surface air temperatures decrease with latitude from an annual average of $-0^{\circ} \mathrm{C}$ in the southwest to $\sim-9^{\circ} \mathrm{C}$ in the north, but air temperatures have been increasing since the 1990s (Thyrring et al. 2017), resulting in declining sea ice coverage (Meredith et al. 2019). Although landfast patches of sea ice form within most fords in the southwest, a large part of southwest Greenland is ice-free in winter, whereas winter ice cover is often established in and above the Disko Bay region $\left(69^{\circ} \mathrm{N}\right)$, and seasonal ice-scour occurs following ice break-up at high latitudes (Gutt 2001, Belt et al. 2009). In addition to sea ice, the Greenland ice sheet discharges large amounts of ice and meltwater into West Greenland fjords at rates which have increased 4-fold in recent decades in the southwest (Bevis et al. 2019), increasing the risk of the intertidal communities being exposed to ice scour. So, temperatures, sea ice coverage and ice scour are all changing latitudinally in Greenland, forming an environmental gradient along the coast. These central environmental factors are expected to contribute to large-scale alterations in Arctic coastal marine communities and productivity along the Greenland coast over space and time (Post et al. 2013, Krause-Jensen and Duarte 2014).

Studying marine ecosystems along this gradient can provide an indication of what to expect at higher latitudes in a warmer future when conditions may be similar to current conditions in the south. Specifically, a quantification of communities and populations along the Greenland coast can provide knowledge on the relative importance of environmental drivers, as well as providing important baseline data for observing and quantifying future changes. For example, latitudinal studies from sub-tidal coastal habitats in Greenland have demonstrated distinct changes in population dynamics, often with depressed growth at increasing latitudes where ice cover is extensive (Blicher et al. 2007, Sejr et al. 2009, Krause-Jensen et al. 2012). For the intertidal realm, studies have focused on the two common blue mussels species, Mytilus edulis and M. trossulus (Mathiesen et al. 2017); blue mussels occur along the entire coastline, and while they can survive exposure to sub-zero air and water temperatures (Thyrring et al. 2015a, 2020), they are confined to protective microhabitats such as, cracks and crevices (Blicher et al. 2013), and their abundance and vertical distribution decrease with latitude (Thyrring et al. 2017). However, quantitative studies of intertidal assemblage structure in Greenland are limited to a few sub-Arctic sites (Høgslund et al. 2014, Sejr et al. 2021).

The aim of the present study was to increase knowledge on Arctic rocky shore assemblage structure and resilience. We quantified latitudinal differences in abundance and biomass of key intertidal species along the West Greenland coast between $60^{\circ} \mathrm{N}$ and $72^{\circ} \mathrm{N}$, and tested the hypotheses that, as abiotic stress increases along the environmental gradient, 1) assemblage composition changes and biomass and coverage decline towards higher (more Arctic) latitudes, and 2) intertidal species are progressively limited to lower intertidal heights at higher latitudes in response to increasing environmental stress.

\section{Material and methods}

\section{Field sampling}

Local environmental conditions affect biomass and communities across small spatial scales. To reduce confounding effects of local-scale processes (e.g. within fjords) on largescale climate related effects (Archambault and Bourget 1996), we sampled a total of 320 plots distributed among 56 rocky intertidal sites in six different regions in West Greenland (Fig. 1). Sampling was conducted in July/August over the years 2011-2013 (Table 1). There are logistic restraints 


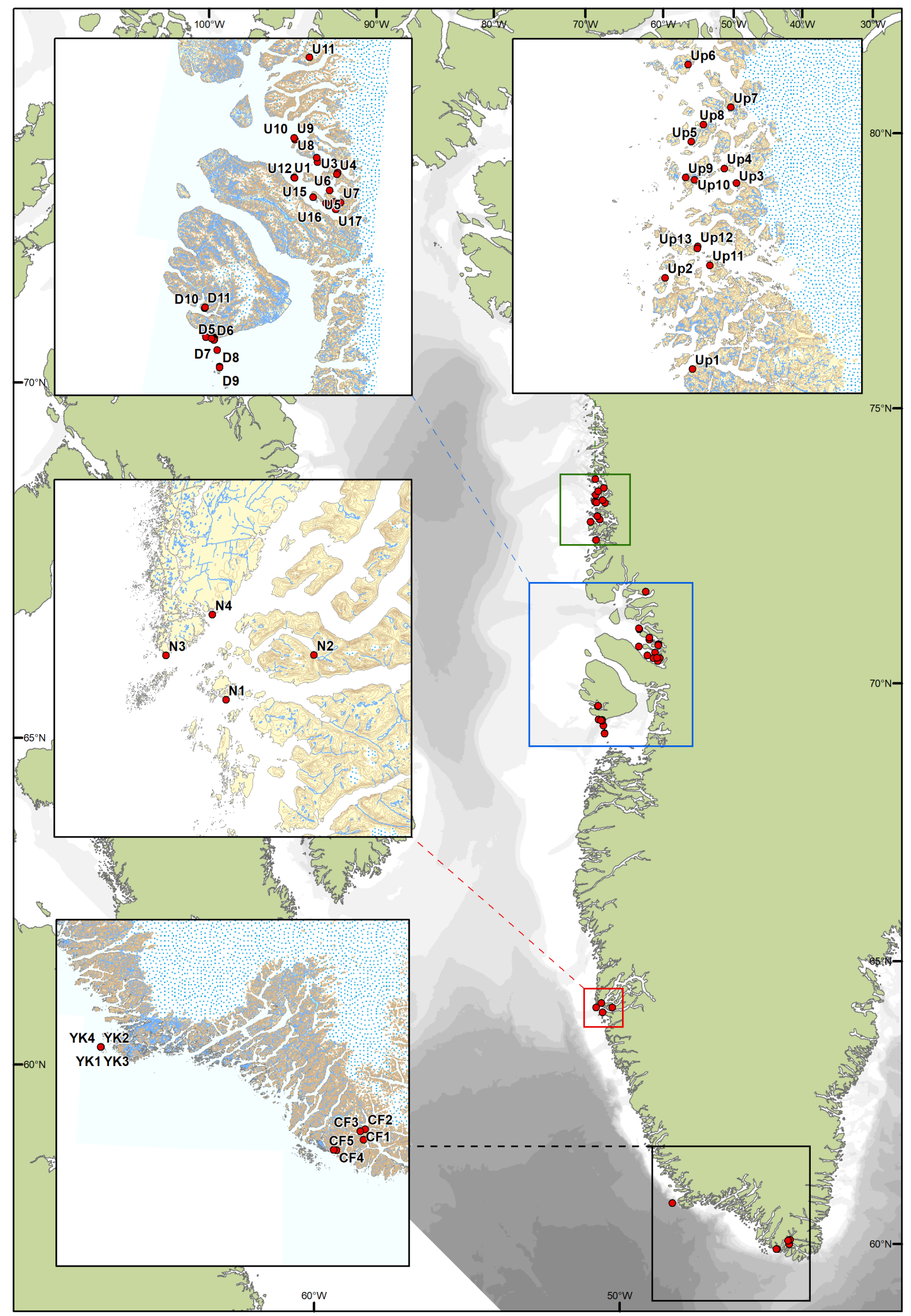

Figure 1. Position of 56 sampling sites nested within six regions in West Greenland: Cape Farewell (sites CF1-CF5), Ydre Kitsissut (sites YK1-YK4), Nuuk (sites N1-N4), Disko Island (sites D1-D12), Uummannaq (sites U1-U18) and Upernavik (sites Up1-Up13). 
Table 1. Environmental characteristics of the six study regions in West Greenland.

\begin{tabular}{|c|c|c|c|c|c|c|}
\hline \multirow[b]{2}{*}{ Environmental factor } & \multicolumn{6}{|c|}{ Fjord } \\
\hline & $\begin{array}{c}\text { Cape Farewell } \\
\left(60^{\circ} \mathrm{N}\right)\end{array}$ & $\begin{array}{c}\text { Ydre Kitsissut } \\
\left(60^{\circ} \mathrm{N}\right)\end{array}$ & $\begin{array}{c}\text { Nuuk } \\
\left(64^{\circ} \mathrm{N}\right)\end{array}$ & $\begin{array}{l}\text { Disko Island } \\
\left(69^{\circ} \mathrm{N}\right)\end{array}$ & $\begin{array}{l}\text { Uummannaq } \\
\qquad\left(71^{\circ} \mathrm{N}\right)\end{array}$ & $\begin{array}{c}\text { Upernavik } \\
\left(72^{\circ} \mathrm{N}\right)\end{array}$ \\
\hline Tidal amplitude $(\mathrm{m})$ & 3.34 & 3.34 & 4.95 & 2.97 & 2.35 & 2.07 \\
\hline Average ice scour (index 0-1) & 0.16 & 0.05 & 0.13 & 0.39 & 0.46 & 0.52 \\
\hline 5th percentile air temperature $\left({ }^{\circ} \mathrm{C}\right)$ & -5.50 & -5.50 & -11.60 & -16.13 & -18.20 & -21.80 \\
\hline Number of sites (sampling year) & $5(2014)$ & $4(2014)$ & $4(2011)$ & $12(2012)$ & $18(2012)$ & $13(2013)$ \\
\hline Average air exposure $\left(\mathrm{hh} \mathrm{d}^{-1}\right)$ & Mid: 6:50 & Mid: $6: 50$ & Mid: 6:50 & Mid: 5:8 & Mid: $10: 2$ & $\begin{array}{l}\text { Mid: } 7: 4 \\
\text { Low: } 4: 4\end{array}$ \\
\hline Maximum air exposure $\left(\mathrm{hh} \mathrm{d}^{-1}\right)$ & Mid: 8:20 & Mid: 8:20 & Mid: 7:20 & Mid: $18: 20$ & Mid: 19:20 & $\begin{array}{l}\text { Mid: } 16: 50 \\
\text { Low: } 6: 20\end{array}$ \\
\hline
\end{tabular}

associated with working in remote Greenland regions where sites were reached by small boats. Thus, site selection was influenced by logistics and weather conditions, but we visited as many sites as possible in each region. Therefore, the number and distribution of sites varies among the six regions, but the aim in all regions was to sample enough sites to capture local variability, which is necessary for an analysis aimed at identifying large scale changes. Thus, the sites were selected to a) represent a range of wave exposure, surface orientation and surface heterogeneity within each region, and b) ensure comparability in those conditions between regions. Sampling was conducted in the mid-intertidal during low tide at transects parallel to the shoreline using seven replicate plots of $0.0625 \mathrm{~m}^{2}(25 \times 25 \mathrm{~cm}$ frames $)$ at each site following the sampling protocol of Høgslund et al. (2014). Within each frame, the total coverage of the intertidal assemblage, including the overhanging canopy from macroalgae attached outside the frame, was visually assessed. After harvest of the canopy-forming algae attached within the frame, the understory coverage of barnacles Semibalanus balanoides was equally assessed. All macroalgal- and macrozoobenthic species (larger than $0.5 \mathrm{~cm}$ ) occurring within the frame, were subsequently collected, sorted, counted (fauna species) and weighed, except for Semibalanus balanoides, for which only coverage was estimated. For all sites, the mid-intertidal was defined as half the maximum tidal amplitude, which was calculated from the Greenland tidal table (obtained from ocean.dmi.dk). The height on the shore was measured following Høgslund et al. (2014). At the northernmost region (Upernavik, Fig. 1) sampling was expanded to also include a lower intertidal level; and seven additional replicates were sampled $30 \mathrm{~cm}$ below the mid-intertidal (Table 1). In all regions and at all sampling sites, the vertical distribution of species was additionally registered along three vertical transect lines extending from the upper distribution limit of intertidal macroalgae to the lowest low water line. For every $25 \mathrm{~cm}$ along each vertical transect (starting from the lower distribution limit), the occurrence of species was recorded along a $20 \mathrm{~cm}$ horizontal line. Data and corresponding tidal heights from the two southern most regions were obtained from Høgslund et al. (2014). At these sites only macroalgae (Cape
Farewell) or canopy forming macroalgae (Ydre Kitsissut) were registered in vertical transects.

Macroalgal species from the frame samples were identified based on Pedersen (2011) to lowest possible taxonomic level using a stereomicroscope. Coverage is presented as 1) total coverage measured as percentage of frame covered before removal of the canopy macroalgae, and 2) understory $S$. balanoides coverage measured after removal of macroalgae. Macroalgal biomass (wet weight, ww) only included species attached inside the frame and was measured in the lab and rounded to the nearest $0.001 \mathrm{~g}$. Macrozoobenthic species were sorted and identified to lowest taxonomic level (Hayward and Ryland 1995), abundances were expressed as number of individuals $0.0625 \mathrm{~m}^{-2}$.

\section{Environmental characteristics}

Four environmental parameters were quantified for each region; length of exposure time to air during low tide, air temperature, sea ice coverage and ice scour. For each sampling locality an annual average and maximum air exposure time per tidal height was calculated based on 2013tidal models (10 min resolution) for the nearest settlements, obtained from the Danish Meteorological Institute (pers. comm. Palle Bo Nielsen, Center for Ocean and Ice). Low air temperature stress can be important in the Arctic region, and the air temperatures were calculated as the 5 th percentile averaged over a ten-year period (year 2007-2016) from data derived from local weather stations in Qaqortoq (station no 4286) Nuuk (station no 4250); Disko Island (station no 4220/4224); Uummannaq (station no 4212/4213) and Upernavik (station no 4210/4211) (Cappelen 2017). We used the 5th percentile because this temperature metric has been shown to correlate with the distribution limit of intertidal blue mussels in Greenland (Thyrring et al. 2020a). The variation in the sea ice coverage period was characterized as a five-year mean based on visible-band images from the MODIS instrument on NASA's Terra satellite. Indications of ice scour were assessed for each replicate plot, resulting in an ice scour index of 0 for no ice scour and 1 for indications of ice scour. A common way of quantifying ice scour is 
measuring the deformation of screws after a winter, with the angle of deformation $\left(0-90^{\circ}\right)$ used as a proxy of ice scouring intensity. This approach require sites to be revisited after the winter, but the actual cost of revisiting all 56 sites in Greenland would be prohibitive. Since grazing impacts are neglectable in Greenland's intertidal zone (Høgslund et al. 2014, Sejr et al. 2021), we measured ice scour as deformation in Fucus sp. If deformities were registered, it was presumed to be caused by ice scouring and the replicate plot was assigned 1. Deformities registered ranged from depauperated and/or damaged thallus, including thallus previous being damaged and from where regrowth is initiated, to complete destruction of plants only leaving reduced and crippled plants within crevices. Analyses of ice scour indications were performed from photos taken before sampling from each replicate plot, and the could only be obtained if vegetation was present within the replicate plots.

\section{Statistical analysis}

Assemblage composition patterns between regions were depicted through ordination by nonmetric multidimentional scaling (nMDS) based on biomass data processed through the 'vegan' package in $\mathrm{R}$ using a Bray-Curtis dissimilarity metric (Oksanen et al. 2018, <www.r-project.org>). Generalized linear mixed effect models (GLMM; 'lme4' R package (Bates et al. 2015)) were used to test for significant effects of latitude on coverage and biomass among regions using within-region sampling sites as a random intercept, as this accounted for dependency among sites located within a region (Zuur et al. 2009, Zuur and Ieno 2016). Length of exposure time to air during low tide, 5th percentile air temperature, sea ice coverage and ice scour were included as explanatory variables in the full models, and all model assumptions were verified by plotting residuals versus fitted values (Zuur et al. 2010, Zuur and Ieno 2016). Following data exploration, biomass was log-transformed, and total coverage and $S$. balanoides coverage was square root-transformed, to avoid overdispersion and to ensure model assumptions were met. Estimated marginal means (EMM) were used to depict the significant effects of regions, using the 'emmeans' $R$ package (Searle et al. 1980, Lenth 2019). Generalized linear models (GLM), were used to test for vertical differences in average number of species, algal biomass, total coverage and $S$. balanoides coverage in the northernmost region where sampling represented both mid-intertidal and lowerintertidal levels. Data were presented using the $\mathrm{R}$ packages 'ggplot2' (Wickham 2016), 'lattice' (Deepayan 2008) and standard deviation $(\mathrm{SD})$.

\section{Results}

\section{Environmental characteristics}

Tidal dynamics along the Greenland coast change from semidiurnal cycles with 3-5 m maximum amplitude at $60-64^{\circ} \mathrm{N}$, to mixed tidal cycles and $2-3 \mathrm{~m}$ amplitude further north (Table 1). Thus, the average and maximum air exposure time during low tide varied among regions. The longest exposure time of $19.4 \mathrm{~h}$ per diurnal cycle in the mid-intertidal zone was recorded in Uummannaq $\left(71^{\circ} \mathrm{N}\right)$ and the shortest $(7.4 \mathrm{~h})$ in Nuuk $\left(64^{\circ} \mathrm{N}\right.$; Table 1$)$. Average fifth percentile air temperatures across years decreased from $-5.5^{\circ} \mathrm{C}$ in Cape Farewell $\left(60^{\circ} \mathrm{N}\right)$ to $-21.8^{\circ} \mathrm{C}$ in Upernavik $\left(72^{\circ} \mathrm{N}\right)$, and the length of the sea ice-covered period increased latitudinally with south Greenland regions (Cape Farewell, Ydre Kitsissut $\left(60^{\circ} \mathrm{N}\right)$, Nuuk) being ice-free year-round, to an ice-covered period of $206 \mathrm{~d}_{\text {year }}{ }^{-1}$ in the northernmost region, Upernavik $\left(72^{\circ} \mathrm{N}\right.$; Table 1$)$. Average ice scour index increased latitudinally from $0.05 \pm 0.23$ at Ydre Kitsissut to $0.52 \pm 0.50$ at Upernavik (Table 1), while glacial ice was observed in all regions, and drift ice from the east coast of Greenland was observed at Cape Farewell.

\section{Assemblage composition}

We registered a total of 46 species in the mid-intertidal zone across six regions and 56 sites, distributed between 29 macroalgal species and 17 macrozoobenthic species. The macroalgal species were represented by 13 Chlorophyta, 11 Ochrophyta and 5 Rhodophyta, and the macrozoobenthic species by 9 Mollusca, 6 Arthropoda, 2 Cnidaria, (Table 2). The nMDS ordination based on biomass (2-dimension, final stress $=0.118$ ) illustrated high similarity of species composition among the six regions (Fig. 2). The most conspicuous difference in species composition from south to north, was that three common species disappeared completely from the mid-intertidal zone along the latitude gradient: The amphipod Gammarus setosus was only found in Cape Farewell $\left(60^{\circ} \mathrm{N}\right)$, while $G$. oceanicus was found in all regions. The gastropod Littorina obtusata, otherwise common, was absent in Upernavik $\left(72^{\circ} \mathrm{N}\right)$, and no mid-intertidal individuals of Ascophyllum nodosum were recorded in the biomass samples north of Nuuk (Table 2), although this species was recorded lower in the tidal zone at Disko Island (Fig. 5).

\section{Abundance, biomass and coverage}

Total biomass ranged from 0 to $2209.9 \mathrm{~g}$ ww $0.0625 \mathrm{~m}^{-2}$ in South Greenland at Ydre Kitsissut, and 0 to $665.2 \mathrm{~g}$ ww $0.0625 \mathrm{~m}^{-2}$ in the Upernavik area (Fig. 3a). There was a significant change in biomass along the latitudinal gradient (GLMM: $\mathrm{p}<0.0001$, Table 3), with a significantly lower biomass at Uummannaq (EMM: $\mathrm{p}=0.0001)$ and Upernavik (EMM: p=0.0004) than Cape Farewell (Fig 3a). This decrease was not significantly correlated to longer duration of ice coverage (GLMM: $\mathrm{p}=0.38$ ), maximum exposure time to air (GLMM: $\mathrm{p}=0.38$ ), air temperatures (GLMM: $\mathrm{p}=0.73$ ) or ice scour (GLMM: $\mathrm{p}=0.19$ ) (Table 3). In the mid-intertidal, canopy-forming brown macroalgal species constituted $>95 \%$ of the biomass. This functional group was dominated by $A$. nodosum, Fucus vesiculosus and $F$. distichus 
Table 2. Species found in the mid-intertidal in six regions along Greenland's west coast $\left(60-72^{\circ} \mathrm{N}\right)$. Please note, that for Ydre Kitsissut, only the fucoid foundation species were sampled together with the associated macrozoobenthic species.

\begin{tabular}{|c|c|c|c|c|c|c|}
\hline \multirow[b]{2}{*}{ Species } & \multicolumn{6}{|c|}{ Fjord } \\
\hline & $\begin{array}{l}\text { Cape Farewell } \\
\left(60^{\circ} \mathrm{N}\right)\end{array}$ & $\begin{array}{l}\text { Ydre Kitsissut } \\
\left(60^{\circ} \mathrm{N}\right)\end{array}$ & $\begin{array}{l}\text { Nuuk } \\
\left(64^{\circ} \mathrm{N}\right)\end{array}$ & $\begin{array}{l}\text { Disko Island } \\
\left(69^{\circ} \mathrm{N}\right)\end{array}$ & $\begin{array}{l}\text { Uummannaq } \\
\left(71^{\circ} \mathrm{N}\right)\end{array}$ & $\begin{array}{c}\text { Upernavik } \\
\left(72^{\circ} \mathrm{N}\right)\end{array}$ \\
\hline \multicolumn{7}{|l|}{ Arthropoda } \\
\hline Gammarus oceanicus & $x$ & $x$ & $x$ & $x$ & $x$ & $x$ \\
\hline Gammarus setosus & $x$ & & & & & \\
\hline Hyale nilssoni & $x$ & & & & & \\
\hline \multicolumn{7}{|l|}{ Cnidaria } \\
\hline Dynamena pumila & & & & $x$ & $x$ & $x$ \\
\hline Laomedea flexuosa & & & & $x$ & $x$ & \\
\hline \multicolumn{7}{|l|}{ Mollusca } \\
\hline Littorina sp. & $x$ & $x$ & & $x$ & & \\
\hline Musculus niger & & & & & & $x$ \\
\hline Mytilus sp. & $x$ & & $x$ & $x$ & $x$ & $x$ \\
\hline Skeneopsis planorbis & $x$ & $x$ & $x$ & & & \\
\hline Turtonia minuta & $x$ & & $x$ & $x$ & & \\
\hline \multicolumn{7}{|l|}{ Chlorophyta } \\
\hline Acrosiphonia arcta & & & & $x$ & $x$ & $x$ \\
\hline Acrosiphonia sp. & & & $x$ & $x$ & $x$ & $x$ \\
\hline Acrosiphonia sonderi & $x$ & & & $x$ & & $x$ \\
\hline Blidingia minima & & & $x$ & & & \\
\hline Cladophora rupestris & & & & $x$ & $x$ & \\
\hline Monostroma grevillei & & & & $x$ & & $x$ \\
\hline Rhizoclonium sp. & & & & & & $x$ \\
\hline Ectocarpus fasciculatus & & & & $x$ & & \\
\hline Ectocarpus siliculosus & & & & $x$ & & \\
\hline Elachista fucicola & & & $x$ & $x$ & & $x$ \\
\hline Fucus sp. & $x$ & $x$ & $x$ & $x$ & $x$ & $x$ \\
\hline $\begin{array}{l}\text { Fucus distichus subsp. } \\
\text { evanescens }\end{array}$ & $x$ & $x$ & $x$ & $x$ & $x$ & $x$ \\
\hline Fucus vesiculosus & $x$ & $x$ & $x$ & $x$ & $x$ & $x$ \\
\hline Isthmoplea sphaerophora & & & & $x$ & $x$ & \\
\hline Petalonia fascia & & & $x$ & & & \\
\hline Pylaiella littoralis & $x$ & & $x$ & $x$ & $x$ & $x$ \\
\hline Sphacelorbus nanus & & & & & & $x$ \\
\hline \multicolumn{7}{|l|}{ Rhodophyta } \\
\hline Bangia fuscopurpurea & & & $x$ & & & \\
\hline Ceramium sp. & & & & $x$ & $x$ & \\
\hline Hildenbrandia rubra & $x$ & & $x$ & & & $x$ \\
\hline Porphyra sp. & & & $x$ & & & \\
\hline $\begin{array}{l}\text { Rhodochorton } \\
\text { purpureum }\end{array}$ & & & & & $x$ & $x$ \\
\hline
\end{tabular}




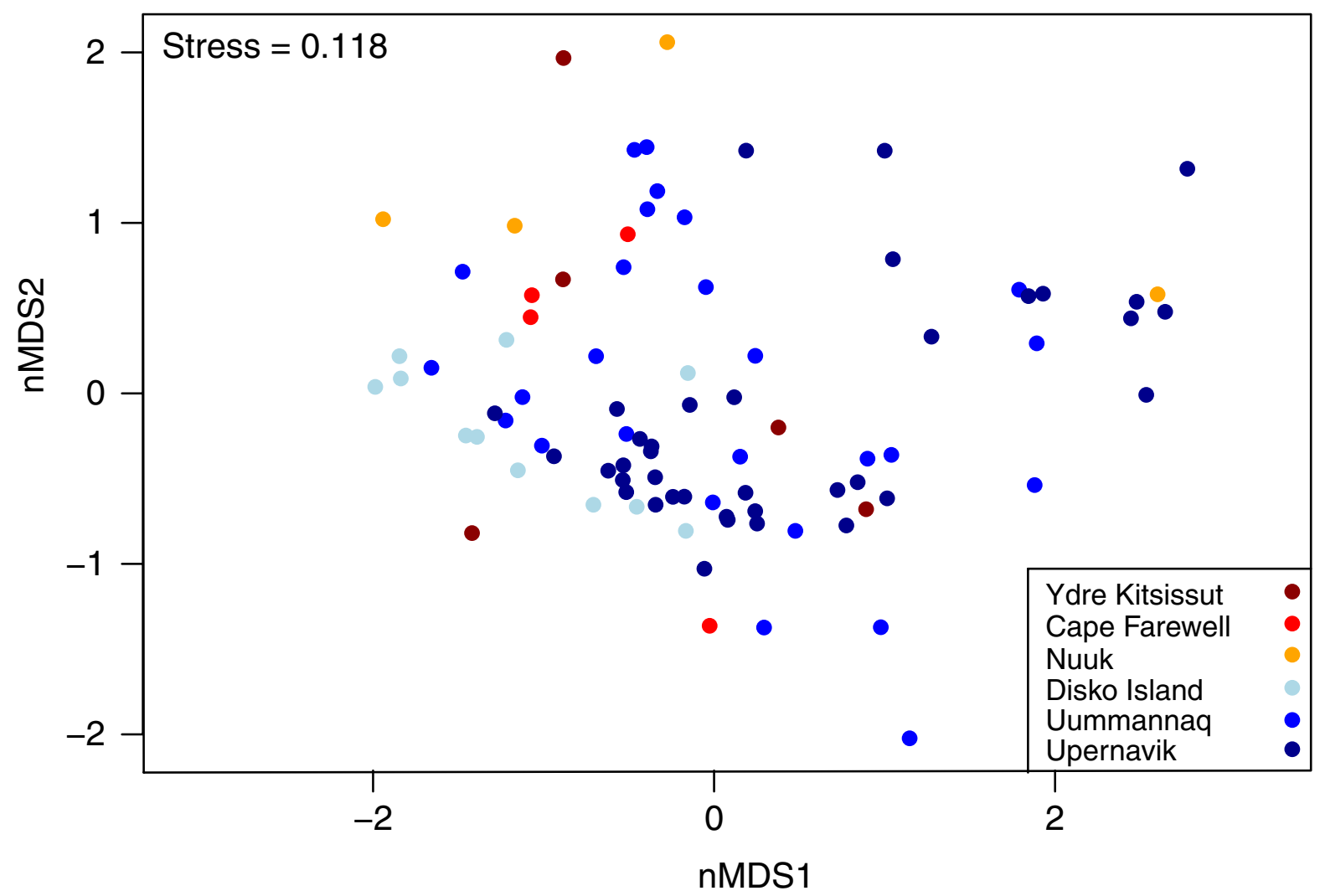

Figure 2. Representation of the species composition of the mid-intertidal assemblage along Greenland's west coast from 60 to $72^{\circ} \mathrm{N}$ visualized through a 2-dimensional nonmetric multidimensional scaling (nMDS) ordination.

subsp. evanescens (Supporting information). Ascophyllum nodosum was found in Cape Farewell and Nuuk with biomasses exceeding $1500 \mathrm{~g}$ ww $0.0625 \mathrm{~m}^{-2}$ and $1300 \mathrm{~g}$ ww $0.0625 \mathrm{~m}^{-2}$, respectively (Fig. 4). Mid-intertidal Fucus spp. were found in all six regions; the highest biomass of $F$. distichus subsp. evanescens was recorded in southern Greenland, while $F$ vesiculosus was most abundant at Ydre Kitsissut and at Disko Island (Fig. 4). The three most abundant macrozoobenthic species were the isopod Jaera albifrons, the blue mussel Mytilus sp. and the grazer Littorina saxatilis, which occurred in densities of $0-1910$ individuals $0.0625 \mathrm{~m}^{-2}$ (Fig. 4).

Total coverage (macroalgae and understory Semibalanus balanoides coverage combined) varied among regions (GLMM: $p=0.003$ ) with a significantly higher coverage at Nuuk compared to Disko Island (MME: $\mathrm{p}=0.02$ ), Uummannaq (MME: $\mathrm{p}=0.003$ ) and Upernavik (MME: $p=0.023$ ). The average total coverage showed a clear decline north of Disko Island from $67.2 \pm 35.3 \%$ at Disko Island to $28.9 \pm 30.1 \%$ at Uummannaq (Fig. 3 b), but neither ice coverage (GLMM: $p=0.58$ ), maximum exposure time to air (GLMM: $p=0.95$ ), air temperatures (GLMM: $p=0.51$ ) or ice scour (GLMM: $p=0.65$ ) correlated significantly with total coverage (Table 3). Semibalanus balanoides coverage displayed no significant differences between regions (Fig. 3c), and a $100 \%$ coverage of the rock surface was found in individual plots in Ydre Kitsissut, Nuuk and Upernavik (Fig. 3c).

\section{Vertical distribution patterns}

The macroalgal vegetation belt occupied $-70 \%$ of the entire tidal amplitude across all regions. This reflect that the dominant macroalgal species (F. vesiculosus and $F$. distichus subsp. evanescens did not change their vertical distributions across latitudes (Fig. 5; A full list of species occurring along the vertical transect lines in each region is available in Supporting information). Likewise, $S$. balanoides inhabited $-70-80 \%$ of the tidal amplitude in all regions where records were obtained. By contrast, the upper distribution limit for $A$. nodosum declined at Disko Island, relative to Cape Farewell and Nuuk further south (Fig. 5). At Upernavik, where an extra set of plots was sampled at $30 \mathrm{~cm}$ below mid-intertidal, there were no significant effects of tidal height on biomass (GLM: $p=0.07$ ), abundance of macrozoobenthic species (GLM: $\mathrm{p}=0.48)$, total coverage (GLM: $\mathrm{p}=0.20)$ or understory coverage (GLM: $\mathrm{p}=0.46$ ) (Fig. 6). 

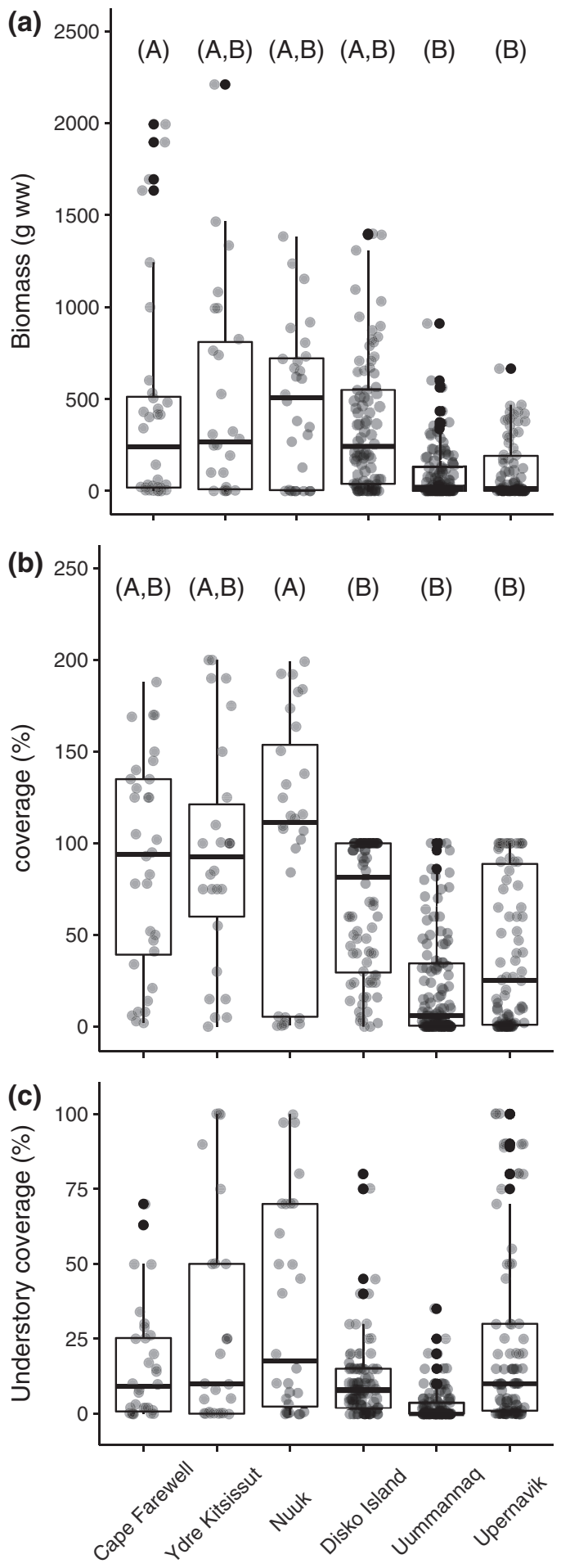

Figure 3. Boxplots of species biomass (g ww) (a), total coverage (\%) (b) and understory Semibalanus balanoides coverage (\%) after removal of macroalgae (c) per frame $\left(0.0625 \mathrm{~m}^{2}\right)$ in six West Greenland regions from 60 to $72^{\circ} \mathrm{N}$. The horizontal line in each boxplot is the median, the boxes define the hinges (25-75\% quartile) and the whisker is 1.5 times the hinges. Black dots represent data outside this range. Letters above boxplots indicate pairwise significance; groups with the same letter do not differ significantly $(\mathrm{p}<0.05)$.

\section{Discussion}

We quantified the mid-intertidal assemblage in West Greenland along a latitudinal gradient from $60^{\circ} \mathrm{N}$ to $72^{\circ} \mathrm{N}$. North of the Disko Island $\left(69^{\circ} \mathrm{N}\right)$, the average biomass was $>50 \%$ lower than in the southernmost regions. However, besides the absence of the foundation species Ascophyllum nodosum in north Greenland, the mid-intertidal assemblage dominance was maintained by a few habitat forming species (i.e. Fucus vesiculosus, F. distichus subsp. evanescens and Semibalanus balanoides) across all latitudes. The conspicuous poleward decline in biomass is consistent with studies on the terrestrial vegetation in West Greenland, which identify a transition zone from sub-Arctic to Arctic vegetation through the northern region of Disko Island (Fredskild 1996). Similar patterns have also been reported for species residing in the subtidal around Greenland. Here the length of sea ice cover explains up to $47 \%$ of the variation in kelp production (Krause-Jensen et al. 2012), and the length of the productive open-water period explains more than $80 \%$ of growth differences among populations of the sea urchin Strongylocentrotus droebachiensis (Blicher et al. 2007). However, we found no significant correlation with air exposure time or 5 th percentile air temperatures, despite a transition zone in tidal regime from semidiurnal to mixed tidal which occurs north of Disko Island, coinciding with decreasing biomasses. Increased exposure time to low air temperatures significantly increases mortality in intertidal benthic species (Aarset 1982, Thyrring et al. 2017), and although most Arctic intertidal sessile organisms are freeze tolerant (Murphy 1983, Thyrring et al. 2020a), few species are capable of surviving extended exposure to sub-zero temperatures. Therefore, survival of benthic species on exposed high Arctic rocky shores depends on microhabitats (crevices or between boulders), biogenic habitats or the ice foot, which is ice forming directly on the rocky surface. Underneath the ice foot, organisms are protected from extreme sub-zero air temperatures in air pockets or saline brine tidepools reached occasionally by water (Scrosati and Eckersley 2007, Clarke and Beaumont 2020). So, although we found no direct effects of air temperatures derived from weather stations, extreme low temperature events in Greenland may restrict species to inhabiting protective microhabitats where temperatures deviate significantly from weather station measurements (Helmuth 1998). For example, a recent study showed that while the average microhabitat temperature on Disko Island was $-3.07^{\circ} \mathrm{C}$, temperatures at the nearby weather station was $-8.04^{\circ} \mathrm{C}$ (Thyrring et al. 2017).

Although, a clear latitudinal pattern in the duration of seasonal ice coverage, and ice scour is evident, we identified no statistical relation between average annual sea ice coverage or ice scour and intertidal assemblage metrics among the six studied regions. There are several potential explanations for this. One explanation is that the export of ice from northeast to south Greenland with the East Greenland Current may cause higher local ice scour frequencies in south Greenland compared to Nuuk and Disko Island (Høgslund et al. 
Table 3. Generalized linear mixed effects model results for the best models with biomass or total coverage of the intertidal assemblage in six regions along Greenland's west coast $\left(60-72^{\circ} \mathrm{N}\right)$ as response variable, air temperature (5th percentile), maximum air exposure, sea ice cover and ice scour as fixed effects, and sites nested within the six regions as random effects.

\begin{tabular}{lcccrrr}
\hline & \multicolumn{4}{c}{ Coefficients fixed effects } & & \\
\cline { 2 - 5 } Response variable & 5th percentile air temperature & Maximum air exposure & Sea ice cover & \multicolumn{1}{c}{ Ice scour } & Variance random effects \\
\hline Biomass & $-0.03, p=0.73$ & $-0.19, p=0.38$ & $-0.19, p=0.38$ & $0.29, p=0.19$ & 0.0583 \\
Total coverages & $-0.03, p=0.51$ & $0.007, p=0.95$ & $0.005, p=0.58$ & $-0.07, p=0.65$ & $<0.0001$ \\
\hline
\end{tabular}

2014). Also, icebergs are locked up for longer in regions with short ice-free summers, reducing scour from drifting ice (Barnes et al. 2014) and the stress from ice scour depends not only on the seasonal presence of ice, but also on the interaction with wave exposure (Heaven and Scrosati 2008), which may result in locally low biomasses at wave-exposed sites not captured in the present study. The potential stress from icescour also depends on the presence of cracks and crevices, as discussed on temperature stress above. Hence, in suitable microhabitats, large standing stocks can develop in the high Arctic; local biomass of $F$. distichus subsp. evanescens was similar in a southern (Nuuk) and northern (Upernavik) region, and $100 \%$ within site macroalgal coverage was also found in all six regions where sites were protected. Furthermore, at sheltered sites in Nuuk seasonally exposed to fast ice, the biomass of $A$. nodosum exceeded $20000 \mathrm{~g} \mathrm{ww} \mathrm{m}^{-2}$, which correspond to biomasses near its distribution center in Canada that range from 11400 to $28900 \mathrm{~g} \mathrm{ww} \mathrm{m}^{-2}$ (Vadas et al. 2004). Thus, our results support the notion that high algal biomass and coverage can be found in the Arctic region when local conditions are favorable (Wulff et al. 2009). Although, we did not measure actual environmental conditions in crevices, we argue that the lack of correlation between intertidal assemblage variables and our environmental measures partly reflects: 1) the buffering role of small-scale conditions such as the presence of crevices and/or a protective ice foot allowing vegetation to develop despite being covered by fast ice and 2) that drifting ice also cause ice scour.

A conclusion from the above is, that the increasing application of macro-ecological analysis, using broadscale environmental data (i.e. remote sensing) that implicitly assume patterns and mechanisms are scale invariant, may not capture the effects of environmental stress on scales relevant to organisms in coastal ecosystems. Combining in situ habitat measurements and experiments with remote sensing data will improve predictability of climate change impacts on coastal assemblage structure and species distribution (Jurgens and Gaylord 2018, Hawkins et al. 2019).

In polar regions, vertical zonation patterns have been described in the the Canadian Arctic where species only inhabit the low intertidal zone (Ellis and Wilce 1961), and on Svalbard and the Antarctic species richness increase from the intertidal towards the subtidal realm (Wulff et al. 2009, Waller 2013). In the present study, we showed that $A$. nodosum is restricted to the low intertidal zone near its northernmost intertidal distribution, and a previous intertidal study showed that blue mussels (Mytilus sp.) are predominantly found in the low intertidal in north Greenland (Thyrring et al. 2017). However, the vertical distribution of the dominant intertidal species shows no change across latitudes; $F$ vesiculosus, $F$. distichus subsp. evanescens and S. balanoides consistently occupied $>70 \%$ of the tidal amplitude. Arctic populations of

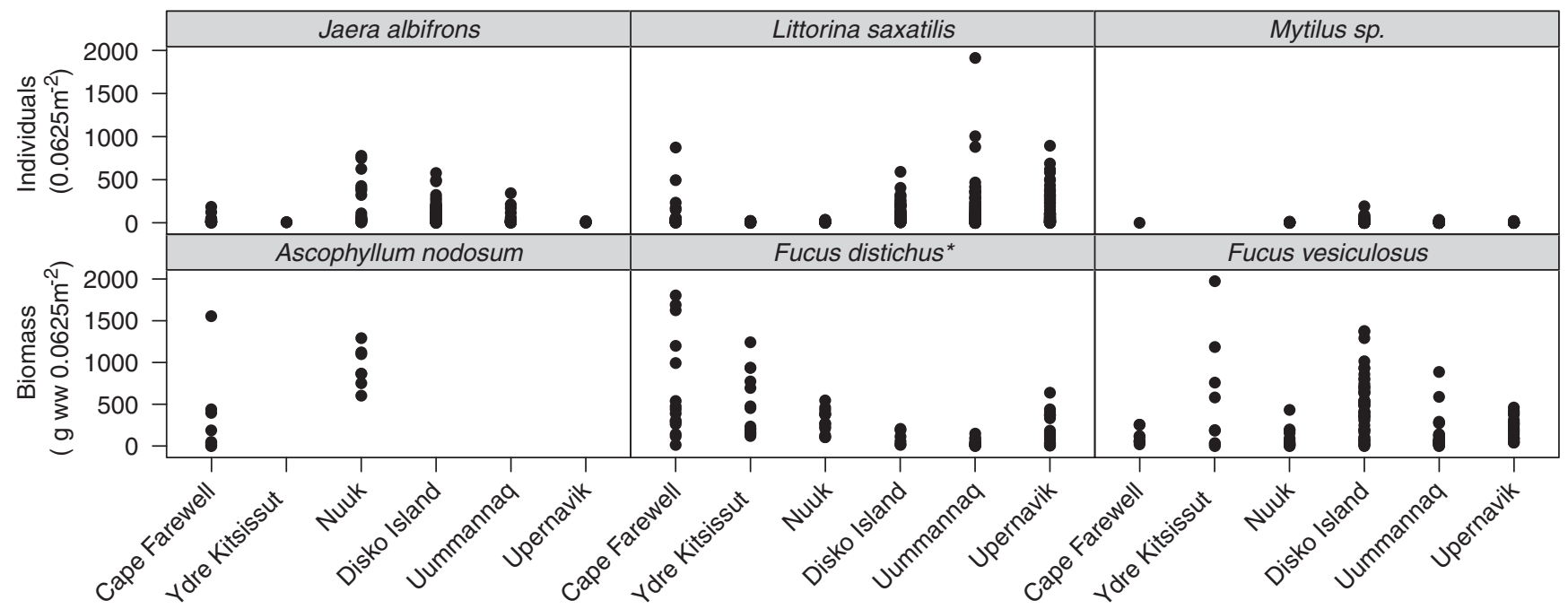

Figure 4. Mid-intertidal biomasses and abundances of the six most common species in six West Greenland regions from 60 to $72^{\circ} \mathrm{N}$. Abundance (Individuals $0.0625 \mathrm{~m}^{-2}$ ): Jaera albifrons, Littorina saxatilis, Mytilus sp. Biomass (g ww $0.0625 \mathrm{~m}^{-2}$ ): Ascophyllum nodosum, Fucus distichus (*Full name Fucus distichus subsp. evanescens) and Fucus vesiculosus. 


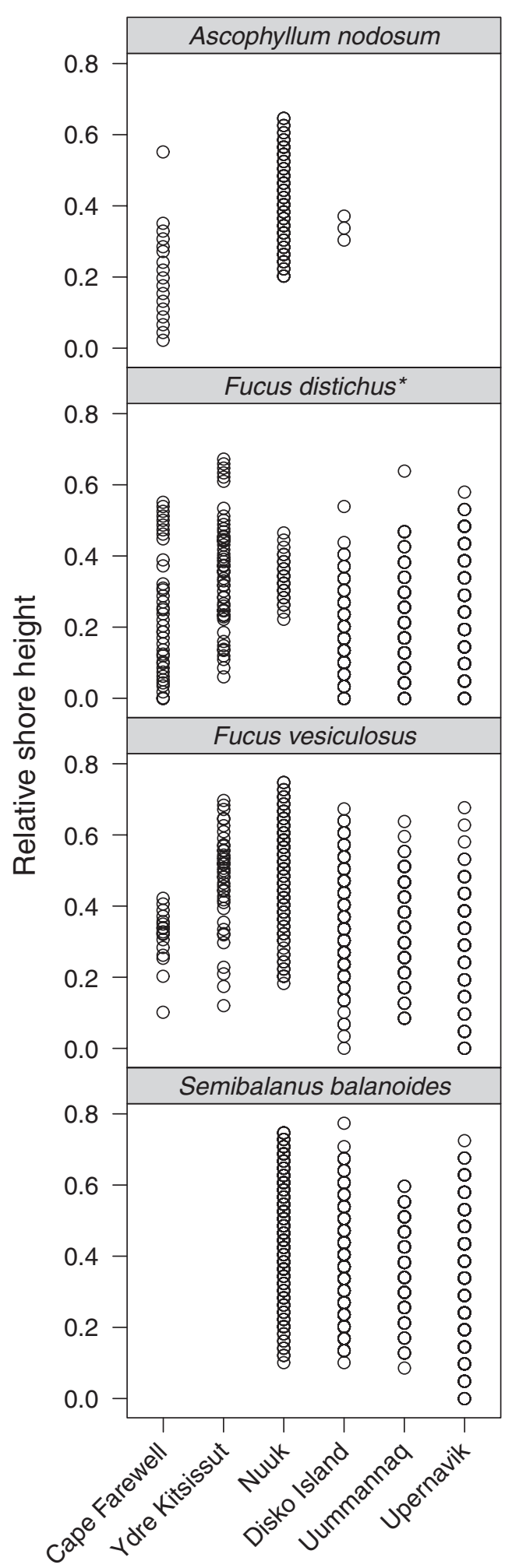

Figure 5. The vertical zonation (relative to max local tidal amplitude) of the four most common species in the intertidal zone in six West Greenland regions from 60 to $72^{\circ} \mathrm{N}$. Ascophyllum nodosum was absent in Uummannaq and Upernavik, and at the two southern most locations (Cape Farewell and Ydre Kitsissut) only macroalgal species were registered at vertical transects. ${ }^{*}$ Full name Fucus distichus subsp. Evanescens.
Fucus spp. can survive extended exposure to sub-zero air temperatures without injury (Parker 1960, Becker et al. 2009), and $M$. edulis and S. balanoides can survive air temperatures below $-10^{\circ} \mathrm{C}$ (Thyrring et al. 2015b, Marshall et al. 2018). Thus, local environmental conditions on scales relevant to the organisms do not induce any vertical changes in the presence of foundation species in north Greenland.

\section{A resilient ecosystem}

Ecosystem resilience is defined as a combination of resistance to severe disturbances, capacity for recovery and the ability to adapt to new conditions (Bernhardt and Leslie 2013). Greenland's intertidal ecosystem is generally dominated by stress tolerant species able to survive extreme environmental stress (Clark et al. 2021), and we argue that the intertidal assemblage has an inherent resistance to climate change. It is possible that a future increase in temperature and a reduction in seasonal sea ice coverage will affect intertidal production and thereby standing stock positively, as suggested for A. nodosum in Greenland (Marbà et al. 2017) and predicted for the subtidal realm (Krause-Jensen and Duarte 2014, Olesen et al. 2015). The resilience is also reflected in that the most abundant and widely distributed foundation species (i.e. Fucus spp.) across the intertidal assemblage, have a strong recovery capacity as they are able to reproduce, grow and recolonize following physical disturbance by ice (Kiirikki and Ruuskanen 1996, Ørberg et al. 2018). Moreover, recent studies have shown local adaptation in intertidal Arctic populations of barnacles $S$. balanoides and blue mussels $M$. edulis in relation to survive sub-zero air temperature exposure (Marshall et al. 2018, Thyrring et al. 2020a) and ocean acidification (Telesca et al. 2019). Thus, West Greenland's intertidal ecosystem seems resilient to gradual climate change, and it is likely that introduced species could pose a greater risk for intertidal assemblages than climate change as increased shipping and propagule transport with the Irminger current increase the potential for introduction of non-native species (Ingolfsson 1992, Renaud et al. 2015). Most marine ectotherms generally fill the entire geographic range within their thermal niche (Sunday et al. 2012). Thus, increasing temperatures may allow species currently residing in temperate regions to expand their distribution poleward, and increase their production and biomass in suitable habitats, as observed in other Arctic regions (Węsławski et al. 2010, Kortsch et al. 2012). Predatory species are known to inhabit and structure rocky intertidal communities in northern temperate areas and south Iceland (Ingólfsson 2004, Thyrring and Peck 2021), and an increased inflow of warm Atlantic water to West Greenland in the 1930s led to large-scale changes in coastal ecosystems, including the arrival of the predatory starfish Asterias rubens (Drinkwater 2006). Asterias rubens and the predatory dogwhelk Nucella lapillus are found in the sublittoral of West Greenland (Mortensen 1932, Thorson 1951, pers. obs. MB), and future climate warming may facilitate an expansion of their distribution into the intertidal, likely altering the structural dynamics of assemblages. This study, 

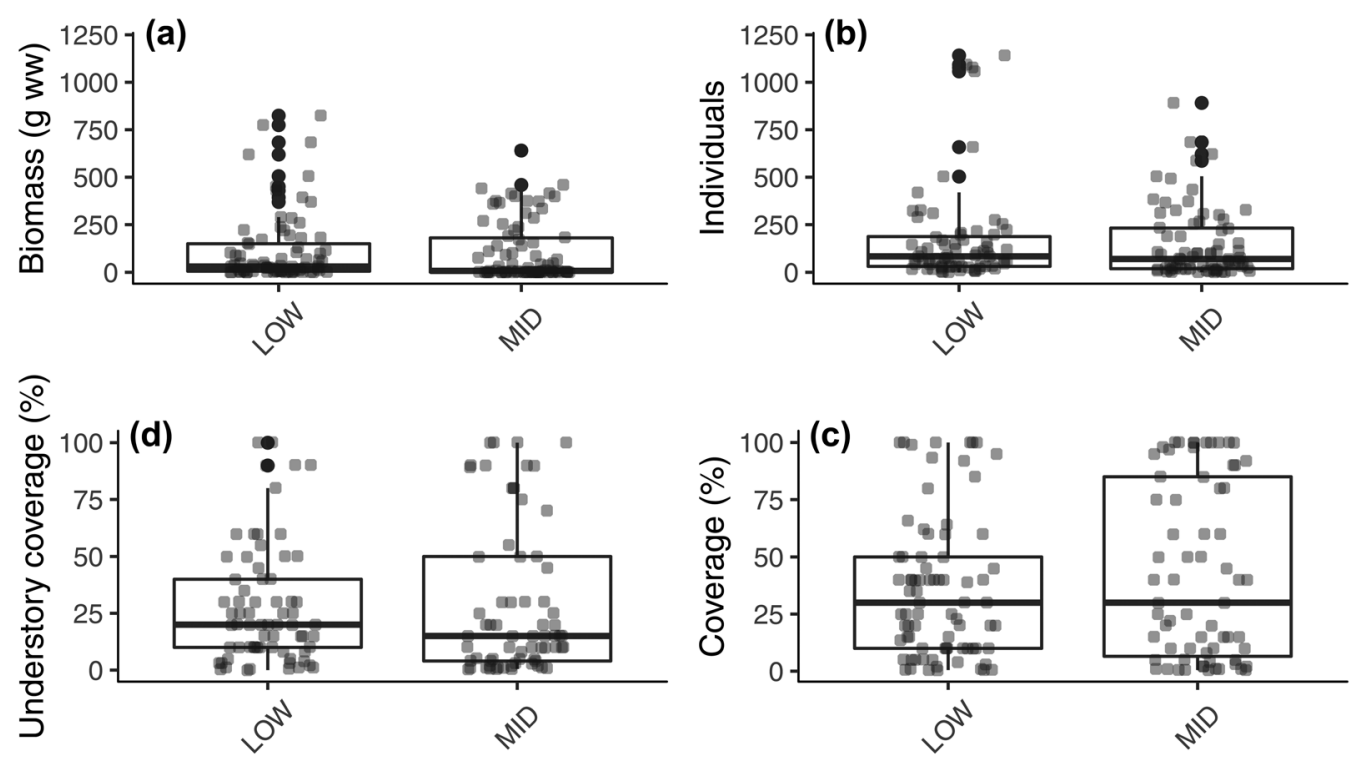

Figure 6. Total biomass (g ww) (a), abundance of macrozoobenthic species (b), total coverage (c) and understory Semibalanus balanoides coverage (d) $0.0625 \mathrm{~m}^{-2}$ at the mid-intertidal (MID) and $30 \mathrm{~cm}$ below the mid-intertidal (LOW) in Upernavik, West Greenland (72 ${ }^{\circ} \mathrm{N}$ ). There were no statistical differences among tidal levels (p-values $>0.05$ ).

therefore, serves as an important baseline to verify such predictions,, as well as for identification of effects of climate change through future monitoring of the intertidal assemblage in Greenland.

Acknowledgements - Peter Bondo Christensen and Nuria Marbà are thanked for help with sampling at Nuuk. This work is a contribution to the Arctic Science Partnership (ASP), and to the Greenland Ecosystem Monitoring program (<https://g-e-m. $\mathrm{dk} />)$.

Funding - Field work was supported by DANCEA, the Greenland Ecosystem Monitoring program (<https://g-e-m.dk/>), and by the Greenland Government through The Environmental Agency for Mineral Resource Activities (EAMRA). J.T. was supported by the Independent Research Fund Denmark (DFF-International Postdoc; contract number 7027-00060B), Aage V. Jensens Fond, and by a Marie Sklodowska-Curie Individual Fellowship (IF; contract number 797387). M.S.E. was supported by the EU H2020 project INTAROS. D.K.J. was supported by the Independent Research Fund Denmark (contract number 8021-00222B, 'CARMA'). L.S.P. was supported by core funds from the UKRI Natural Environment Research Council.

\section{Author contributions}

Jakob Thyrring: Data curation (equal); Formal analysis (lead); Investigation (equal); Methodology (equal); Project administration (equal); Validation (equal); Visualization (lead); Writing - original draft (lead). Susse Wegeberg: Conceptualization (equal); Funding acquisition (equal); Investigation (equal); Methodology (equal); Writing - review and editing (equal). Martin Blicher: Conceptualization (equal); Funding acquisition (equal); Investigation (equal); Methodology (equal); Writing - review and editing (equal). Dorte Krause-Jensen: Conceptualization (equal); Funding acquisition (equal); Investigation (equal); Methodology (equal); Writing - review and editing (equal). Signe Høgslund: Conceptualization (equal); Funding acquisition (equal); Investigation (equal); Methodology (equal); Writingreview and editing (equal). Birgit Olesen: Conceptualization (equal); Investigation (equal); Methodology (equal); Writing - review and editing (equal). Jozef Wiktor: Formal analysis (supporting); Investigation (equal); Methodology (equal); Writing - review and editing (equal). Kim N. Mouritsen: Conceptualization (equal); Funding acquisition (equal); Investigation (equal); Methodology (equal); Writing - review and editing (equal). Lloyd Peck: Methodology (equal); Supervision (equal); Writing - review and editing (equal). Mikael Sejr: Conceptualization (equal); Funding acquisition (equal); Investigation (equal); Methodology (equal); Project administration (equal); Supervision (lead); Writing - review and editing (equal).

\section{Transparent Peer Review}

The peer review history for this article is available at https:// publons.com/publon/10.1111/ecog.05381.

\section{Data availability statement}

Raw data available on Zenodo <http://doi.org/10.5281/ zenodo.3920535> (Thyrring et al. 2020). Weather data is available from the Danish Meteorological Inst (<www. research.dmi.dk>).

\section{References}

Aarset, A. V. 1982. Freezing tolerance in intertidal invertebrates - a review. - Comp. Biochem. Physiol. A 73: 571-580. 
AMAP. 2017. Snow, Water, Ice and Permafrost in the Arctic (SWIPA) 2017. - ArcticMonitoring and Assessment Programme (AMAP), Oslo, Norway.

Archambault, P. and Bourget, E. 1996. Scales of coastal heterogeneity and benthic intertidal species richness, diversity and abundance. - Mar. Ecol. Prog. Ser. 136: 111-121.

Barnes, D. K. A. et al. 2014. Climate-linked iceberg activity massively reduces spatial competition in Antarctic shallow waters. - Curr. Biol. 24: R553-R554.

Barry, J. P. et al. 1995. Climate-related, long-term faunal changes in a California rocky intertidal community. - Science 267: 672-675.

Bates, D. et al. 2015. Fitting linear mixed-effects models using lme4. - J. Stat. Softw. 67: 1-48.

Becker, S. et al. 2009. Freezing tolerance and photosynthetic performance of polar seaweeds at low temperatures. - Bot. Mar. 52: 609-616.

Belt, K. et al. 2009. Intertidal barnacles as indicators of the intensity of scour by sea ice. - Mar. Ecol. Prog. Ser. 381: 183-187.

Bernhardt, J. R. and Leslie, H. M. 2013. Resilience to climate change in coastal marine ecosystems. - Ann. Rev. Mar. Sci. 5: 371-392.

Bevis, M. et al. 2019. Accelerating changes in ice mass within Greenland, and the ice sheet's sensitivity to atmospheric forcing. - Proc. Natl Acad. Sci. USA 116: 1934-1939.

Blicher, M. E. et al. 2007. Growth and production of sea urchin Strongylocentrotus droebachiensis in a high-Arctic fjord, and growth along a climatic gradient $\left(64\right.$ to $\left.77^{\circ} \mathrm{N}\right)$. - Mar. Ecol. Prog. Ser. 341: 89-102.

Blicher, M. E. et al. 2013. Population structure of Mytilus edulis in the intertidal zone in a sub-Arctic fjord, SW Greenland. Mar. Ecol. Prog. Ser. 487: 89-100.

Cappelen, J. 2017. Weather observations from Greenland 1958 to 2016 - observation data with description. - Danish Meteorological Inst. (DMI), Copenhagen, Denmark, 31 pp.

Clark, M. et al. 2021. Resilience in Greenland intertidal Mytilus: the hidden stress defense. - Sci. Total Env. 767: 144366.

Clarke, A. and Beaumont, J. C. 2020. An extreme marine environment: a 14-month record of temperature in a polar tidepool. - Polar Biol. 43: 2021-2030.

Deepayan, S. 2008. Lattice: multivariate data visualization with R. - Springer.

Drinkwater, K. F. 2006. The regime shift of the 1920s and 1930s in the North Atlantic. - Prog. Oceanogr. 68: 134-151.

Ellis, D. V 1955. Some observations on the shore fauna of Baffin Island. - Arctic 8: 224-236.

Ellis, D. V. and Wilce, R. T. 1961. Arctic and subarctic examples of intertidal zonation. - Arctic 35: 224-235.

Fredskild, B. 1996. A phytogrographical study of the vascular plants of West Greenland $\left(62^{\circ} 20^{\prime}-74^{\circ} 00^{\prime} \mathrm{N}\right)$. - Meddelelser Om Grønland, Copenhagen Denmark, Bioscience 45: 158 pp.

Gutt, J. 2001. On the direct impact of ice on marine benthic communities, a review. - Polar Biol. 24: 553-564.

Hawkins, S. J. et al. 2019. The intertidal zone of the north-east Atlantic Region. - In: Hawkins, S. J. et al. (eds), Interactions in the marine benthos. Cambridge Univ. Press, pp. 7-46.

Hayward, B. W. and Ryland, J. S. 1995. Handbook of the marine fauna of north-west Europe. - Oxford Univ. Press.

Heaven, C. S. and Scrosati, R. A. 2008. Benthic community composition across gradients of intertidal elevation, wave exposure and ice scour in Atlantic Canada. - Mar. Ecol. Prog. Ser. 369: 13-23.
Helmuth, B. et al. 2002. Climate change and latitudinal patterns of intertidal thermal stress. - Science 298: 1015-1017.

Helmuth, B. S. T. 1998. Intertidal mussel microclimates: predicting the body temperature of a sessile invertebrate. - Ecol. Monogr. 68: $51-74$.

Høgslund, S. et al. 2014. Intertidal community composition along rocky shores in south-west Greenland: a quantitative approach. - Polar Biol. 37: 1549-1561.

Ingolfsson, A. 1992. The origin of the rocky shore fauna of Iceland and the Canadian Maritimes. - J. Biogeogr. 19: 705.

Ingólfsson, A. 1996. The intertidal seashore of Iceland and its animal communities. - Zool. Icel. 1: 1-85.

Ingólfsson, A. 2004. Community structure and zonation patterns of rocky shores at high latitudes: an interocean comparison. - J. Biogeogr. 32: 169-182.

Jurgens, L. J. and Gaylord, B. 2018. Physical effects of habitatforming species override latitudinal trends in temperature. Ecol. Lett. 21: 190-196.

Kiirikki, M. and Ruuskanen, A. 1996. How does Fucus vesiculosus survive ice scraping? - Bot. Mar. 39: 133-139.

Kortsch, S. et al. 2012. Climate-driven regime shifts in Arctic marine benthos. - Proc. Natl Acad. Sci. USA 109: 14052-14057.

Krause-Jensen, D. and Duarte, C. M. 2014. Expansion of vegetated coastal ecosystems in the future Arctic. - Front. Mar. Sci. 1: 77.

Krause-Jensen, D. et al. 2012. Seasonal sea ice cover as principal driver of spatial and temporal variation in depth extension and annual production of kelp in Greenland. - Global Change Biol. 18: 2981-2994.

Kuklinski, P. and Barnes, D. K. A. 2008. Structure of intertidal and subtidal assemblages in Arctic vs. temperate boulder shores. Polish Polar Res. 39: 203-218.

Lantuit, H. et al. 2012. The Arctic coastal dynamics database: a new classification scheme and statistics on Arctic permafrost coastlines. - Estuar. Coast. 35: 383-400.

Lenth, R. 2019. emmeans: estimated marginal means, aka leastsquares means. R package ver. 1.4.3.01.-<https://cran.r-project. org/web/packages/emmeans/>.

Marbà, N. et al. 2017. Climate change stimulates the growth of the intertidal macroalgae Ascophyllum nodosum near the northern distribution limit. - Ambio 46: 119-131.

Marshall, K. E. et al. 2018. Transcriptional dynamics following freezing stress reveal selection for mechanisms of freeze tolerance at the poleward range margin in the cold water intertidal barnacle Semibalanus balanoides. - bioRxiv, doi: 10.1101/449330.

Mathiesen, S. S. et al. 2017. Genetic diversity and connectivity within Mytilus spp. in the subarctic and Arctic. - Evol. Appl. 10: 39-55.

Meredith, M. et al. 2019. Polar Regions. - In: Pörtner, H.-O. et al. (eds), IPCC special report on the ocean and cryosphere in a changing climate. The Intergovernmental Panel of Climate Change (IPCC), Geneva, Switzerland.

Mortensen, T. 1932. The Godthaab expedition 1928 echinoderms. Meddelelser Om Grønland, Copenhagen, Denmark, pp. 1-62.

Murphy, D. J. 1983. Freezing resistance in intertidal invertebrates. - Annu. Rev. Physiol. 45: 289-299.

Oksanen, J. et al. 2018. vegan: community ecology package. R package ver. 2.5-3. - <https:/CRAN.R-project.org/ package $=$ vegan $>$.

Olesen, B. et al. 2015. Eelgrass (Zostera marina L.) in subarctic Greenland: dense meadows with slow biomass turnover. - Mar. Ecol. Prog. Ser. 518: 107-121. 
Ørberg, S. B. et al. 2018. Canopy-forming macroalgae facilitate recolonization of sub-arctic intertidal fauna and reduce temperature extremes. - Front. Mar. Sci. 5: 332.

Parker, J. 1960. Seasonal changes in cold-hardiness of Fucus vesiculosus. - Biol. Bull. 119: 474-478.

Pedersen, M. P. 2011. Grønlands Havalger. - Epsilon, Copenhagen, Denmark.

Pitt, N. R. et al. 2010. Climate-driven range changes in Tasmanian intertidal fauna. - Mar. Freshwater Res. 61: 963-970.

Post, E. et al. 2013. Ecological consequences of sea-ice decline. Science 341: 519-524.

Renaud, P. E. et al. 2015. The future of Arctic benthos: expansion, invasion and biodiversity. - Prog. Oceanogr. 139: 244-257.

Sanford, E. et al. 2019. Widespread shifts in the coastal biota of northern California during the 2014-2016 marine heatwaves. - Sci. Rep. 9: 4216.

Scrosati, R. and Eckersley, L. K. 2007. Thermal insulation of the intertidal zone by the ice foot. - J. Sea Res. 58: 331-334.

Searle, S. R. et al. 1980. Population marginal means in the linear model: an alternative to least squares means. - Am. Stat. 34: 216-221.

Sejr, M. K. et al. 2009. Sea ice cover affects inter-annual and geographic variation in growth of the Arctic cockle Clinocardium ciliatum (Bivalvia) in Greenland. - Mar. Ecol. Prog. Ser. 389: 149-158.

Sejr, M. K. et al. 2021. Small scale factors modify impacts of temperature, ice scour and waves and drive rocky intertidal community structure in a Greenland fjord. - Front. Mar. Sci. 7: 607135.

Sorte, C. J. B. et al. 2017. Long-term declines in an intertidal foundation species parallel shifts in community composition. Global Change Biol. 23: 341-352.

Sunday, J. M. et al. 2012. Thermal tolerance and the global redistribution of animals. - Nat. Clim. Change 2: 686-690.

Telesca, L. et al. 2019. Biomineralization plasticity and environmental heterogeneity predict geographical resilience patterns of foundation species to future change. - Global Change Biol. 25: 4179-4193.

Thorson, G. 1951. The Godthaab expedition 1928: Scaphopoda, Placophora, Solenogastres, Gastropoda Prosobranchiata, Lamellibranchiata. - Meddelelser om Grønland.

Thyrring, J. and Peck, L. S. 2021. Global gradients in intertidal species richness and functional groups. - eLife 10: e64541.
Thyrring, J. et al. 2015a. Metabolic cold adaptation and aerobic performance of blue mussels Mytilus edulis along a temperature gradient into the High Arctic region. - Mar. Biol. 162: 235-243.

Thyrring, J. et al. 2015b. Does acute lead (Pb) contamination influence membrane fatty acid composition and freeze tolerance in intertidal blue mussels in arctic Greenland? - Ecotoxicology 24: 2036-2042.

Thyrring, J. et al. 2017. Rising air temperatures will increase intertidal mussel abundance in the Arctic. - Mar. Ecol. Prog. Ser. 584: 91-104.

Thyrring, J. et al. 2020a. Local cold adaption increases the thermal window of temperate mussels in the Arctic. - Conserv. Physiol. 7: coz098.

Thyrring, J. et al. 2020b. Data from: Latitudinal patterns in intertidal ecosystem structure in West Greenland suggest resilience to climate change. - Zenodo, <http://doi.org/10.5281/ zenodo.3920535>.

Vadas, S. R. L. et al. 2004. Biomass and productivity of intertidal rockweeds (Ascophyllum nodosum LeJolis) in Cobscook Bay. Northeast. Nat. 11: 123-142.

Waller, C. L. 2013. Zonation in a cryptic Antarctic intertidal macrofaunal community. - Antarct. Sci. 25: 62-68.

Węsławski, J. M. et al. 1993. Intertidal zone of svalbard: macroorganism distribution and biomass. - Polar Biol. 13: 73-79.

Węsławski, J. M. et al. 2010. Increase in biodiversity in the arctic rocky littoral, Sorkappland, Svalbard, after 20 years of climate warming. - Mar. Biodivers. 40: 123-130.

Węsławski, J. M. et al. 2018. Range extension of a boreal amphipod Gammarus oceanicus in the warming Arctic. - Ecol. Evol. 8: 7624-7632.

Wickham, H. 2016. ggplot2: elegant graphics for data analysis. Springer-Verlag, New York, USA, viii + 213 pp.

Wulff, A. et al. 2009. Biodiversity, biogeography and zonation of marine benthic micro- and macroalgae in the Arctic and Antarctic. - Bot. Mar. 52: 491-507.

Zuur, A. F. and Ieno, E. N. 2016. A protocol for conducting and presenting results of regression-type analyses. - Methods Ecol. Evol. 7: 636-645.

Zuur, A. F. et al. 2009. Mixed effects models and extensions in ecology with R. - Springer.

Zuur, A. F. et al. 2010. A protocol for data exploration to avoid common statistical problems. - Methods Ecol. Evol. 1: 3-14. 